\title{
Lethal Violence and Peripheral Youth Extermination in Brazil Amazon Region
}

\author{
Jean-François Yves Deluchey ${ }^{1, *}$ and Amanda Laysi Pimentel Dos Santos ${ }^{2}$ \\ ${ }^{1}$ PhD in Political Science from Sorbonne Nouvelle University (Paris 3); Professor in Universidade Federal do \\ Pará. Coordinator of the "Institutions and Punitive Dispositives Study Center (CESIP)", Brazil \\ ${ }^{2}$ Law Graduate from Universidade Federal do Pará, UFPA; Junior Research Scholar of the "Institutions and \\ Punitive Dispositives Study Center (CESIP)", Brazil
}

\begin{abstract}
This work aims to discuss the homicide problem in the Brazilian Amazon region, based on the analysis of data collected by DATASUS, Sangari and Ipea Institute on homicides in Brazil, which were systematized within the framework of the "Amazonias: Knowledge and Changes" project, and by interviews analysis carried out with relatives of victims of the region. Based on these studies, which point out that the main victims of this type of violence are youth from the peripheries and using the notion of sociodiversity, we try to understand how violence against this youth maintained relation with neoliberalism set of governmental practices, as described by Michel Foucault in The Birth of Biopolitics. In this way, we think possible to provide a synthesis of the major problems of lethal violence and extermination of peripheral youth in the Amazon Region.
\end{abstract}

Keywords: Lethal Violence, Amazon Region, Peripheral Youth Extermination.

\section{INTRODUCTION}

Quantitative data on violence and security in Brazil usually lack of reliability. Therefore, any research which seeks to think about these questions from secondary data produced by the brazilian statistics systems must show great caution in analyzing the data and in its conclusions. The lack of systematization and the fact that the data are mostly produced by the same police officers that are the objects of the evaluation are both factors that complicate every statistical study on these matters. In the research project "Amazônias: Conhecimento e Mudanças" (Amazonias: Knowledge and Changes), the same methodological proposal was used in 15 areas of social observation (Bank Credit, Agriculture, Pollution, etc. $)^{1}$. The objetive was to construct an analysis based on quantitative databases, using the same econometrics indicators in every area. The scarcity of studies on violence and security using similar methodology alone testifies of the difficulty of this attempt, and we confess that, at first, we had great doubts about the heuristic value of this methodology for our area.

*Address correspondence to this author at the Institutions and Punitive Dispositives Study Center (CESIP); Brazil; E-mail: jfdeluchey@gmail.com

\footnotetext{
${ }^{1}$ This research project was coordinated by Professor Maurilio Monteiro (Pará South-East University - UNIFESSPA). Jean-François Deluchey coordinated the subproject on the area of security (based on homicide rates).
}

However, considering the limitations of statistics extracted from state criminal records, quantitative studies that want to analyze data on violent crime (especially at a municipal level) have no other option than to work upon the data bank built by the Brazilian Ministry of Health (DATASUS - Health United System Data Bank). Obviously, possible DATASUS registry failures can not be ruled out, but this database remains the best available option for a researcher who wants to study the phenomena of violence and crime from secondary data in Brazil.

Despite these limitations, it is still possible to acheive a study based on data available in DATASUS, and try to product scientific knowledge upon violence in Brazil and Amazon Region. The proposal of the project seeks to examine the municipal data of the territory "Legal Amazon" (federated states of Acre, Amazonas, Amapá, Mato Grosso, Pará, Rondônia, Roraima, Tocantins and western part of Maranhão), comparing DATASUS data on violence with the demographic data of the last two national census in Brazil (2000 and 2010).

In this perspective, we also used the reports of the Sangari Institute, which shows the evolution of homicides in Brazil, and by the Brazilian Institute of Applied Economics (IPEA), which recently launched an "Atlas of Violence". With this data, it is possible to design the main tendencies of lethal violence in Brazil and the Amazon: both of those data indicate that the main victim of this violence has been the peripheral youth people. In this study, we first choose to expose 
the quantitative data obtained by this recent studies, analysing the frequency and variation of the homicide rate in Amazonia between 2000 and 2010 and later. Secondly, we studied more particularly the problem of the extermination of the peripheral youth through a qualitative research we carried out in spring 2017, the which consisted in two hours interviews with several relatives of victims of extermination in the region, in order to understand how violence against this youth maintains relation with neoliberal set of governmental practices, as described by Michel Foucault in The Birth of Biopolitics. Based on these two studies, we have finally tried to draw a sketch of prognosis to better contribute to the control of violent crime in the Amazon and Brazil.

\section{The Homicide in the Legal Amazon (2000/2010)}

Aiming to perceive some of the numerous aspects of the inequality that affects the Amazon region as compared with the rest of Brazil in the public safety area, we propose to observe how the violent criminality situation changed in this region in the last intercensorial period, that is, between 2000 and 2010. Founded on the "DATASUS" data from the Brazilian Ministry of Health, we observed the frequency and the variation of the phenomenon in the period, and we studied particularly with which type of weaponry the referred homicides had been perpetrated. In order to classify the data, based on international research standards in the same filed of investigation, we established different levels for the analysis of the homicide rate per 100.000 inhabitants in Brazil and in the Legal Amazon:

1. Rate between 0 and 10: Low

2. Rate between 10 and 20: Medium

3. Rate between 20 and 35: High

4. Rate bigger than or equal to 35: Very High

The "DATASUS"data bank indicates that Brazil, had a homicide 27,7 rate per 100.000 inhabitants in 2000 and 26,6 in 2010. On this period, even if the number of homicides in Brazil stays high, between 47.000 and 51.000 homicides in 2000 and 2010, and even if the number of homicides grew on the period of $7,9 \%$, the Brazilian population grew even more $(12,3 \%)$. This fact seems to be great news at national level and, in a matter of fact, with an lower increase of homicides than population growth, the homicide rate per 100.000 inhabitants on Brazil decreased by 3,9\% between 2000 and 2010.
In the Amazon Region, the evolution was completely different: not only the number of homicides doubled in the period $(107,6 \%$ increase, from 3.906 to 8.110 between 2000 and 2010), this increase is approximately five times greater than the population growth $(21,1 \%)$, which configures a situation of total lack of crime control, and one of complete failure from the public forces in confronting the violent criminality in Amazon Region. As a result, the amazon region increased its homicide rate per 100.000 inhabitants by $71,5 \%$ between 2000 and 2010 !

If we observe the other regions (see Table 1, following), the "DATASUS" informs that the Northern/Amazon Region is the Region in which the homicide rate most increased between 2000 and 2010 in Brazil, just ahead from the North-East Region, with a $87,1 \%$ homicide rate increase. The northeastern rate appears as much as worrying as northern, principally if we take into consideration that the population growth have been relatively low in the period $(11,2 \%)$.

In the same period, the South Region experienced a $33,6 \%$ increase of its homicide rate per 100.000 inhabitants. This is not good news, especially if we consider that the population growth in the Region was only $9,1 \%$ below the national average $(12,3 \%)$. The Mid-West Region (without the Amazon State of Mato Grosso) knew an increase of $13,0 \%$ of its homicide rate, with a population growth of $20,6 \%$. The good performance of Mato Grosso made the rate of this region fall from $13,0 \%$ to $3,3 \%$. Finally, the Southeast Region (Rio de Janeiro, São Paulo, Minas Gerais) had the best performance of the Brazilian regions in the confronting of the lethal violence, by reaching a $46,6 \%$ fall of its homicide rate, which passed from 37,3 to 19,9 homicides per 100.000 inhabitants between 2000 and 2010, when the region's population growth on the period was of only $11,0 \%$.

Mostly, the number of Brazilian municipalities in which were registered homicides grew in an exponential way between 2000 and 2010. In 2000, 1.408 of the 5.508 municipal districts we studied registered a case of homicide. In 2010, the "DATASUS" registered homicides in 2.492 districts. The difference means an increase of almost $77 \%$ of the number of municipalities reached by lethal violence! When in 2000 , only $25,6 \%$ of the municipalities had registered homicide, in 2010 , this number reached $45,2 \%$ of all the 5.508 brazilian municipal districts.

In the Amazon Region, the situation seems even more critical: in 2000 only 205 of the 756 Amazon 
Table 1: Homicide Rate Per 100.000 Inhabitants - 2000/2010 - Brazil/Regions

\begin{tabular}{|c|c|c|c|c|c|c|c|c|c|}
\hline & $\begin{array}{c}\text { Number } \\
\text { of } \\
\text { Homicide } \\
2000\end{array}$ & $\begin{array}{c}\text { Number of } \\
\text { inhabitants } \\
2000\end{array}$ & $\begin{array}{c}\text { Homicide } \\
\text { Rate per } \\
100.000 \\
\text { inhabitants } \\
2000\end{array}$ & $\begin{array}{c}\text { Number of } \\
\text { Homicides } \\
2010\end{array}$ & $\begin{array}{c}\text { Number of } \\
\text { inhabitants } \\
2010\end{array}$ & $\begin{array}{c}\text { Homicide } \\
\text { Rate per } \\
100.000 \\
\text { inhabitants } \\
2010\end{array}$ & $\begin{array}{l}\text { Variation } \\
\text { on the } \\
\text { number of } \\
\text { homicides } \\
2000 / 2010\end{array}$ & $\begin{array}{c}\text { Variation } \\
\text { of the } \\
\text { homicide } \\
\text { rate per } \\
100.000 \\
\text { inhabitants } \\
2000 / 2010\end{array}$ & $\begin{array}{l}\text { Population } \\
\text { Growth } \\
2000 / 2010\end{array}$ \\
\hline BRAZIL & 47094 & 169799170 & 27,7 & 50825 & 190732694 & 26,6 & $7,9 \%$ & $-3,9 \%$ & $12,3 \%$ \\
\hline LEGAL AMAZON & 3906 & 20.127 .831 & 19,4 & 8110 & 24.366 .290 & 33,3 & $107,6 \%$ & $71,5 \%$ & $21,1 \%$ \\
\hline NORTH & 2517 & 12900704 & 19,5 & 5839 & 15865678 & 36,8 & $132,0 \%$ & $88,6 \%$ & $23,0 \%$ \\
\hline $\begin{array}{l}\text { NORTHEAST } \\
\text { (total) }\end{array}$ & 9893 & 47741711 & 20,7 & 18512 & 53078137 & 34,9 & $87,1 \%$ & $68,3 \%$ & $11,2 \%$ \\
\hline $\begin{array}{l}\text { NORTHEAST } \\
\text { (except the } \\
\text { Amazon part of } \\
\text { Maranhão }\end{array}$ & 9470 & 43018937 & 22,0 & 17162 & 47611516 & 36,0 & $81,2 \%$ & $63,7 \%$ & $10,7 \%$ \\
\hline SOUTH & 4280 & 25107616 & 17,0 & 6238 & 27384815 & 22,8 & $45,7 \%$ & $33,6 \%$ & $9,1 \%$ \\
\hline $\begin{array}{c}\text { MID - WEST } \\
\text { (except Mato } \\
\text { Grosso) }\end{array}$ & 2439 & 9132375 & 26,7 & 3324 & 11016349 & 30,2 & $36,3 \%$ & $13,0 \%$ & $20,6 \%$ \\
\hline $\begin{array}{l}\text { MID - WEST } \\
\text { (total) }\end{array}$ & 3405 & 11636728 & 29,3 & 4245 & 14050340 & 30,2 & $24,7 \%$ & $3,3 \%$ & $20,7 \%$ \\
\hline SOUTHEAST & 26999 & 72412411 & 37,3 & 15991 & 80353724 & 19,9 & $-40,8 \%$ & $-46,6 \%$ & $11,0 \%$ \\
\hline
\end{tabular}

Source: Amazônias: Conhecimento e Mudanças. DATASUS.

municipalities had registered at least one homicide; in 2010, 391 municipalities registered at least one homicide, configuring an increase of more than $90 \%$ ! This means that, when in 2000 , only $27,1 \%$ of the municipalities in the Amazon region had registered homicides, in $2010,51,7 \%$ of the same ones experienced this phenomenon.

When we try to deepen the analysis using the maps of the variation of the number of homicides in each municipality in the period of 2000/2010, we can observe that these evolutions are even more visible (See Maps 1 to 4). The intensification of the lethal violence concerns two regions in particular:

1) the Amazon outback (pioneer frontiers of national rural development with the extension of the soy harvesting and the intensification of the mineral extracting activities);

2) the northeastern coast, especially in the federated State of Ceará and the southeast part of the coast (Bahia, Sergipe, Alagoas).

Besides illustrating a particular increase of homicide events in the North / Amazon Region, the Maps $\mathbf{5}$ and 6 (following) show how much this increase was concentrated in specific territories of the Amazon
Region between 2000 and 2010, notably in the south of the federated State of Pará (in its border with the State of Mato Grosso), and the eastern part of Pará, with

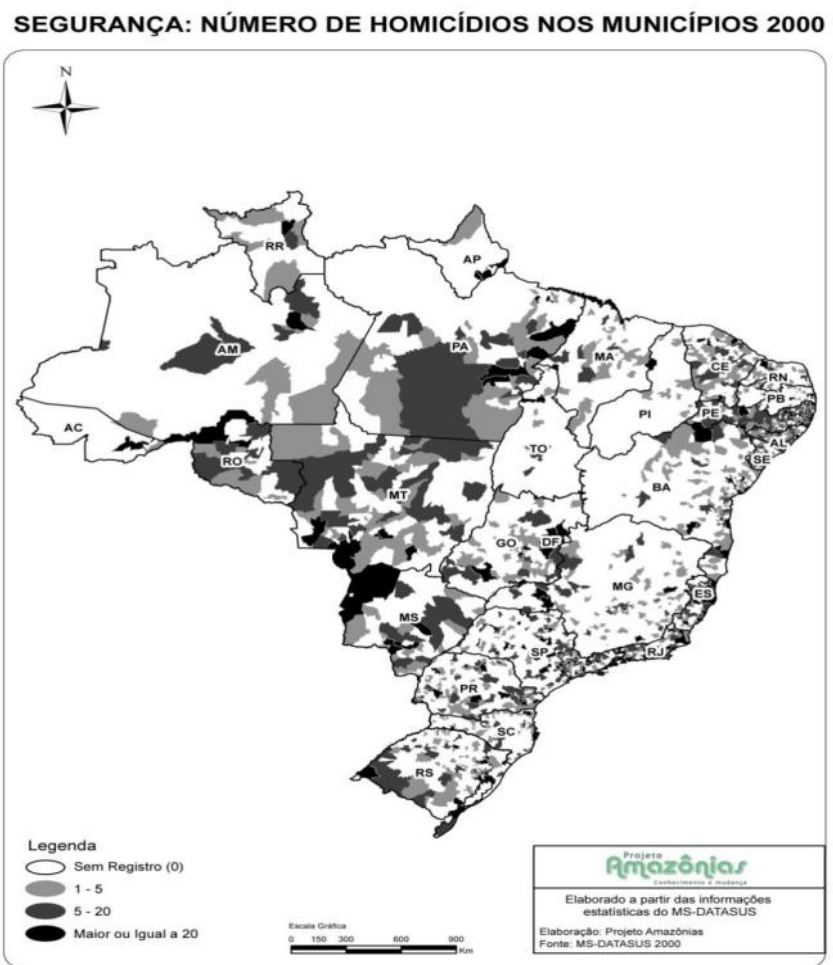

Map 1: Safety: Number of homicides (municipalities, 2000). 


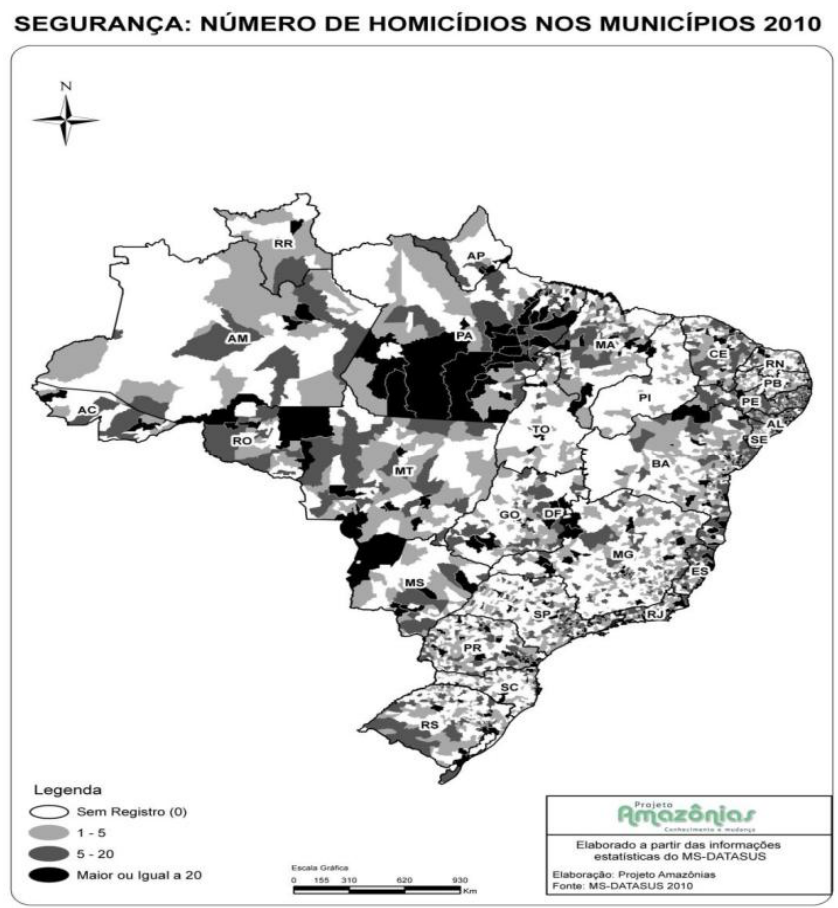

Map 2: Safety: Number of homicides (municipalities, 2010).

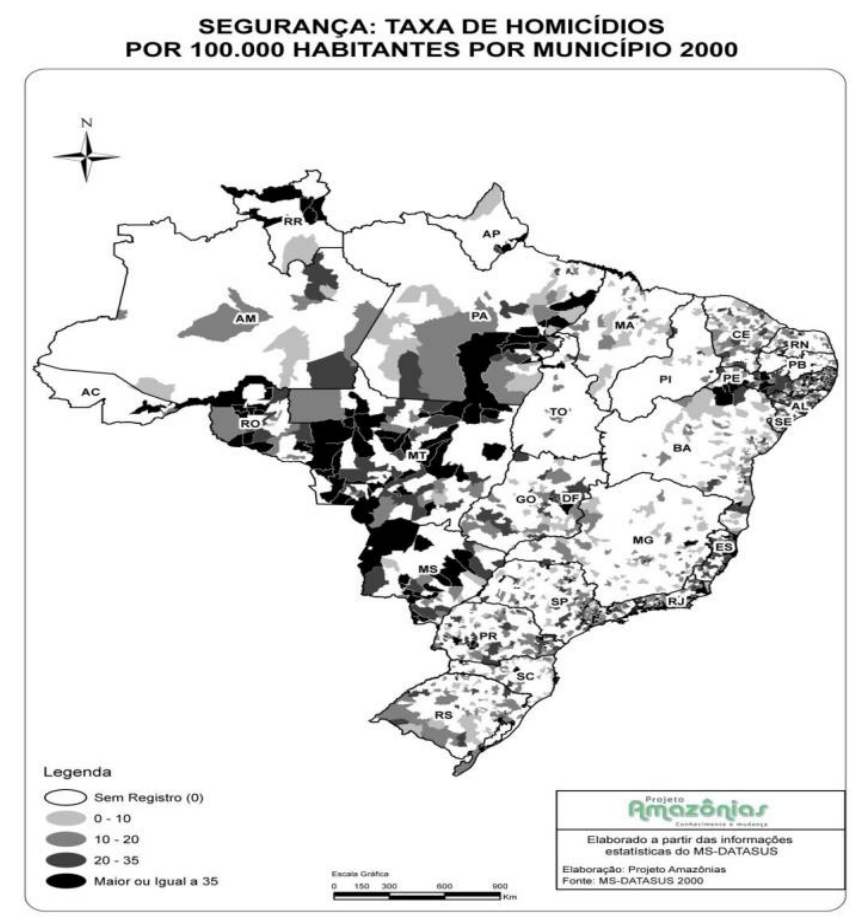

Map 3: Safety: Homicide rate per 100.000 inhabitants (municipalities, 2000).

outspreads in Maranhão, Tocantins, and in the borders between these three States. We can also observe a similar growth on the borders of Mato Grosso and Rondônia, and in those of Roraima with Amazonas. At least in the mostly rural regions of the Amazon, the homicides seem to follow the pioneer fronts of deforestation and intensification of human activities (mining and soy).

SEGURANCA: TAXA DE HOMICIDIOS POR 100.000 HABITANTES POR MUNICIPPIO 2010

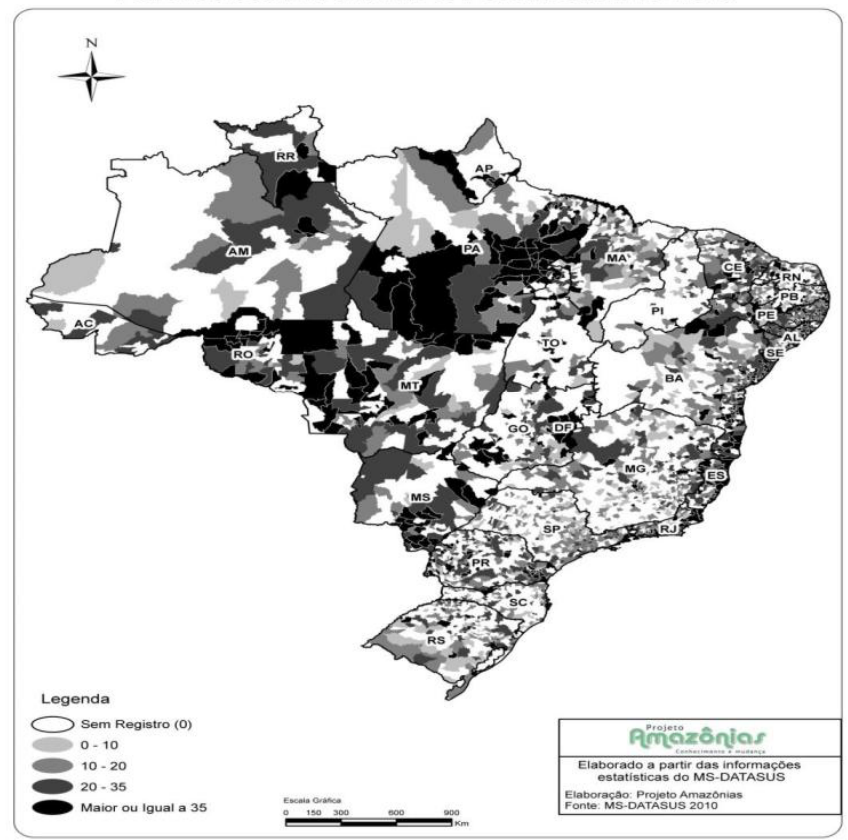

Map 4: Safety: Homicide rate per 100.000 inhabitants (municipalities, 2010).

In relation to the evolution of the homicide rate, the Maps 7 and 8 (following) show an intensification of the homicides per inhabitant in the east and south regions of the State of Pará, and in the borders Rondônia-Mato Grosso, Roraima-Amazonas and in the State of Acre. In the Maps 9 and 10 (following), we try to correct the distorted effect created by the adinistrative design of the Amazon municipal territories, adopting diferent method of visualization (scatter plots), and it appears that the homicide rate in the period increases mostly in the triple border between the federated States of Pará, Tocantins and Maranhão, in the border between Pará and Mato Grosso, in the west of Pará in the BR-163 area, in the northeast of the Legal Amazon (Maranhão and Pará), in the State of Tocantins as a whole (although the biggest concentration is situated in the border zone, known as the "parrot's beak", in the north of the state).

Unfortunately, we must wait for the next population census of 2020 to verify the evolution followed by the lethal violence in the current decade. However, the Sangari Institute evaluates every year this evolution, from populational balance and data from "DATASUS". IPEA has also recently published a report that can indicate the lethal violence inflexions in Brazil and in the Amazon since 2010. 


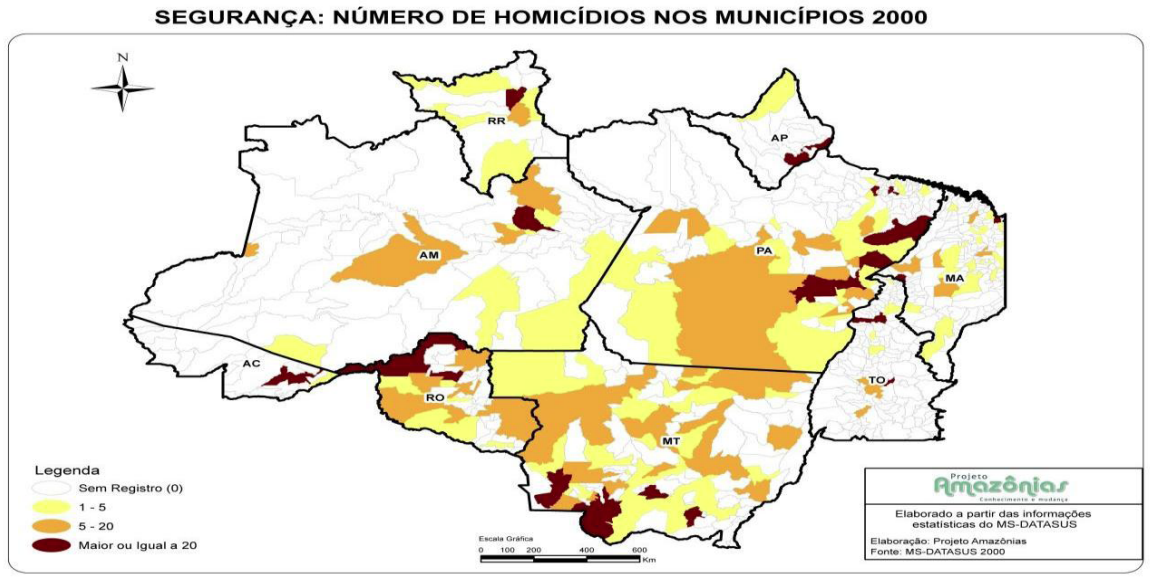

Map 5: Number of homicides in the legal amazon municipalities, 2000.

SEGURANÇA: NÚMERO DE HOMICÍDIOS NOS MUNICÍPIOS 2010

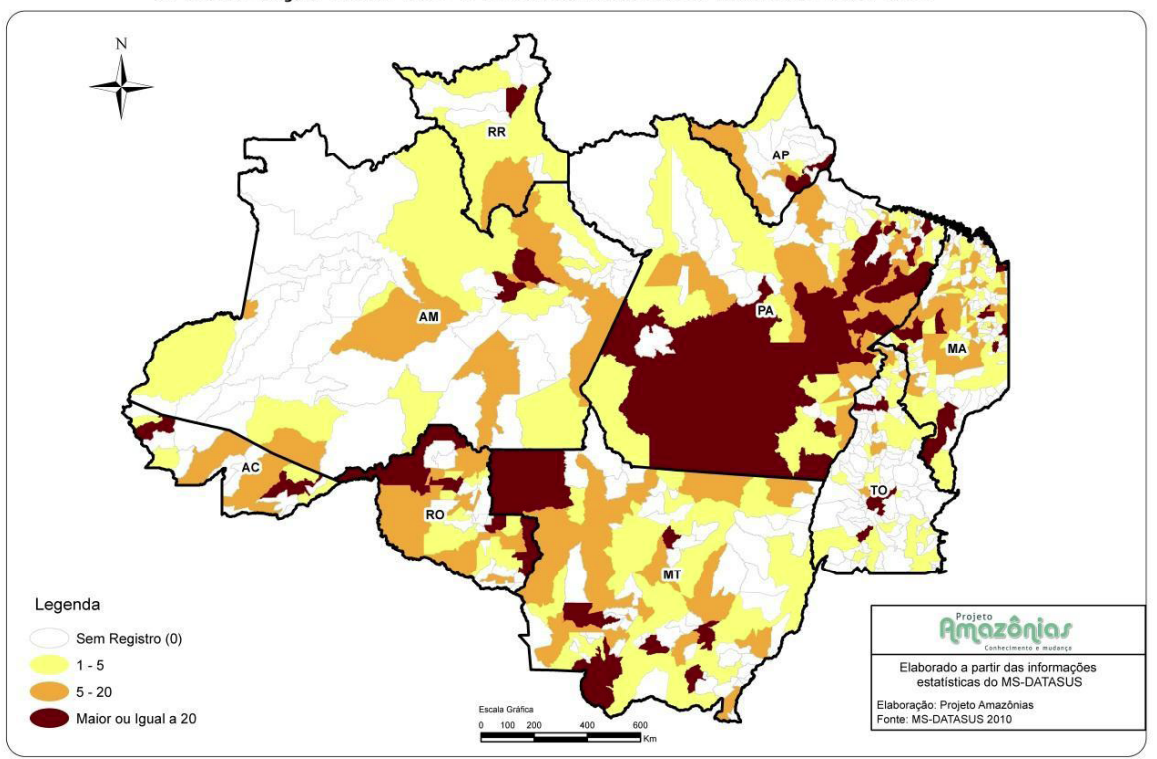

Map 6: Number of homicides in the legal amazon municipalities, 2010.

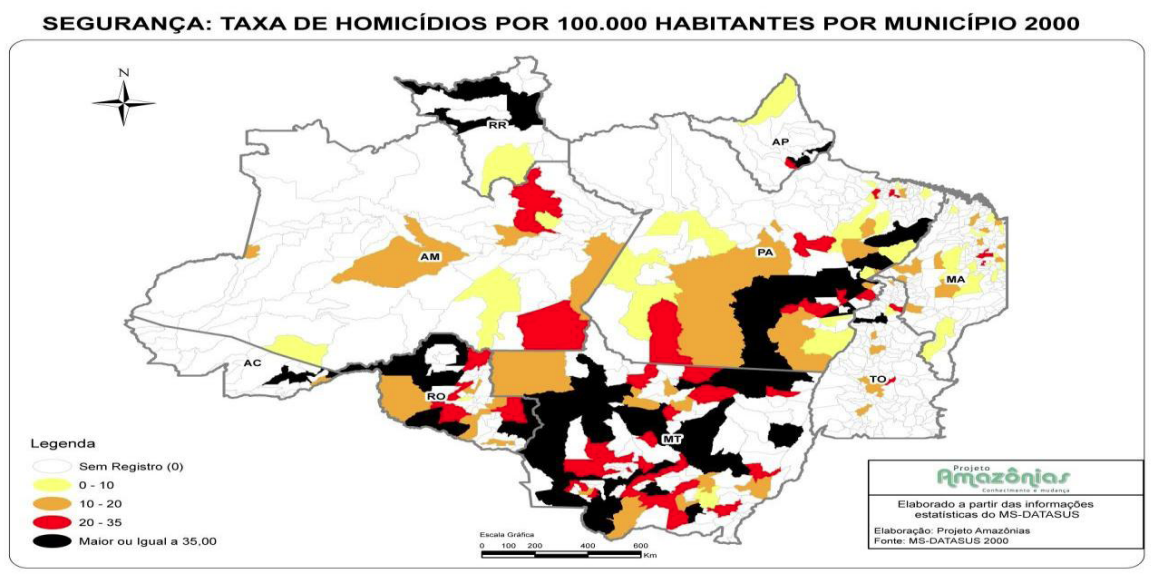

Map 7: Homicide rate per 100.000 inhabitants in the legal amazon municipalities, $2000\left(1^{\text {ST }}\right.$ visualization, municipal area). 


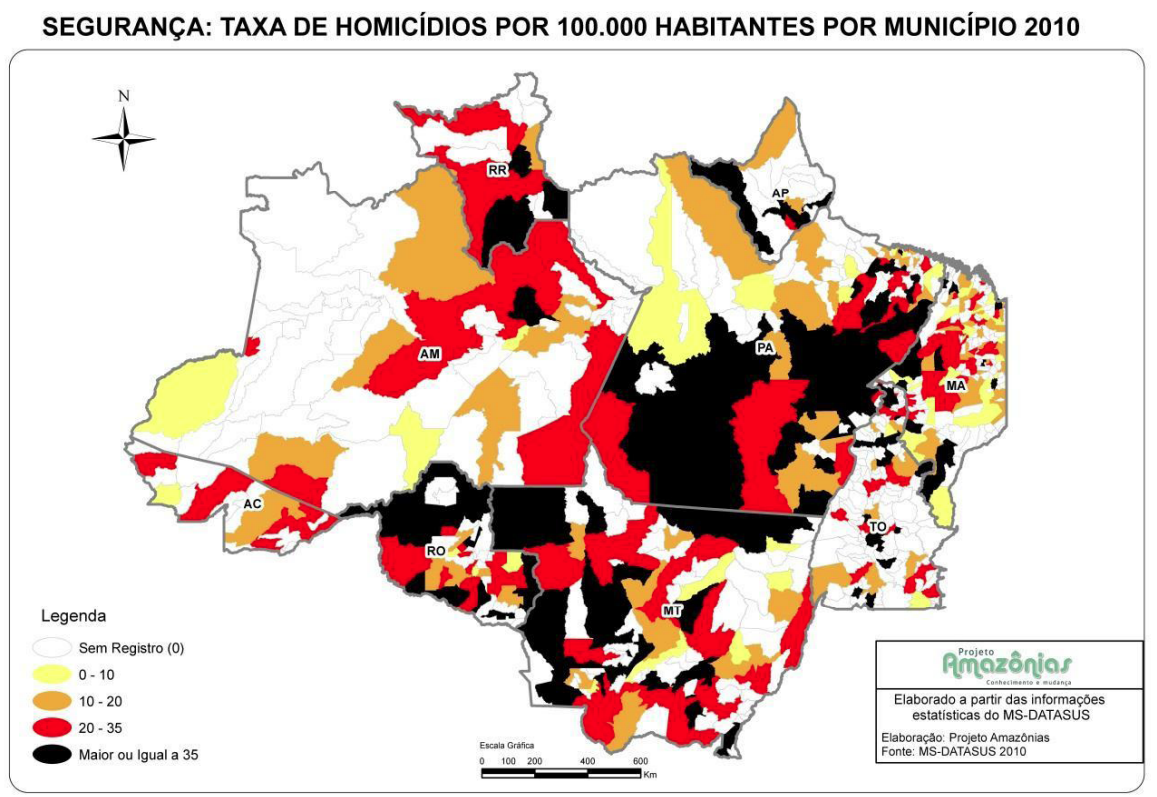

Map 8: Homicide rate per 100.000 inhabitants in the legal amazon municipalities, 2010 (1 ${ }^{\text {ST }}$ visualization, municipal area).

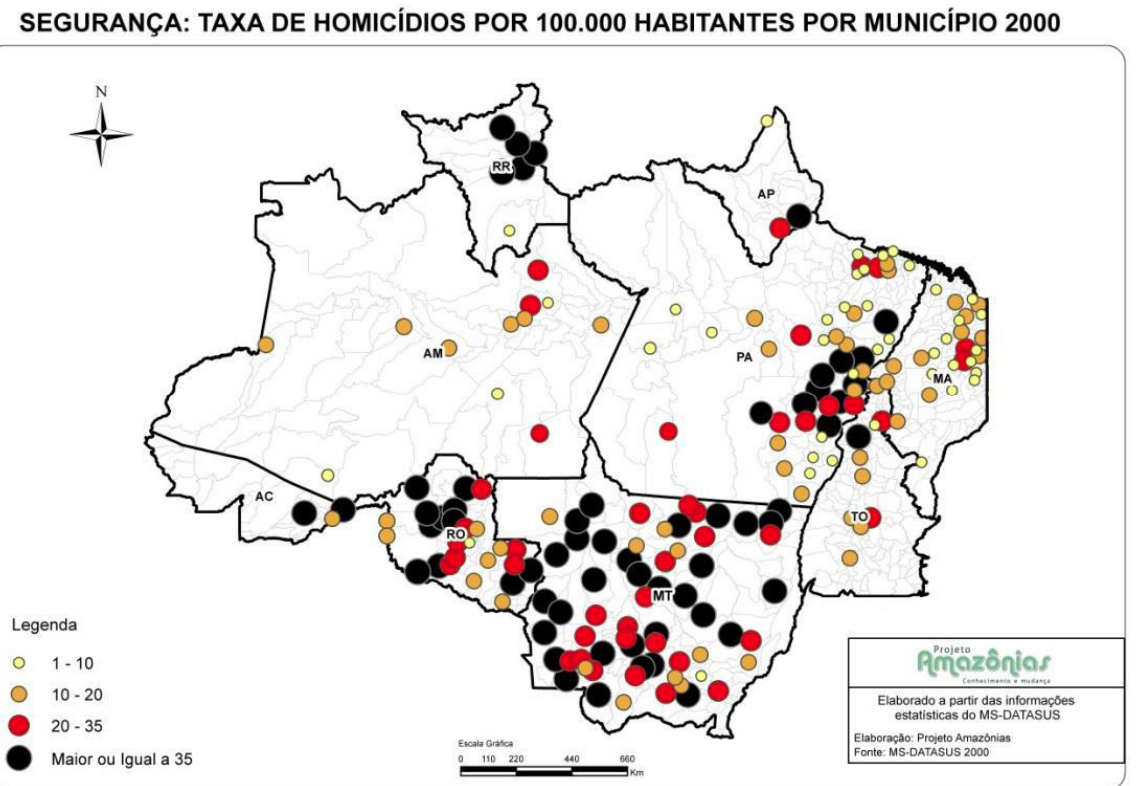

Map 9: Homicide rate per 100.000 inhabitants in the legal amazon municipalities, 2000 ( ${ }^{\mathrm{ND}}$ visualization, scatter plots).

\section{The Evolution of Homicides in the Amazon (2010-} 2017)

In the recent years, the occurrence of deaths by firearm has been considerably increasing in the whole country. According to data from the "Map of Violence" $(2016)^{2}$, that analyzed the evolution of the homicides

${ }^{2}$ WAISELFISZ, J.J. Map of violence 2016: Homicides by firearm. Brasília, UNESCO, 2016. by firearm between 1980 and 2014, approximately 1 million people (967.851) were shot down by some kind of firearm in Brazil. In the observed period, the study points that in Brazil there was a considerable increase of $415,1 \%$ of victims, demonstrating that the problem of gunshot mortality assumed gigantic proportions. The appointed main reason to the increasing of deaths, in the referred study, are the gunshot homicides, that during the analyzed period, represented $85,5 \%$ of the total of these deaths. 
SEGURANÇA: TAXA DE HOMICÍDIOS POR 100.000 HABITANTES POR MUNICÍPIO 2010

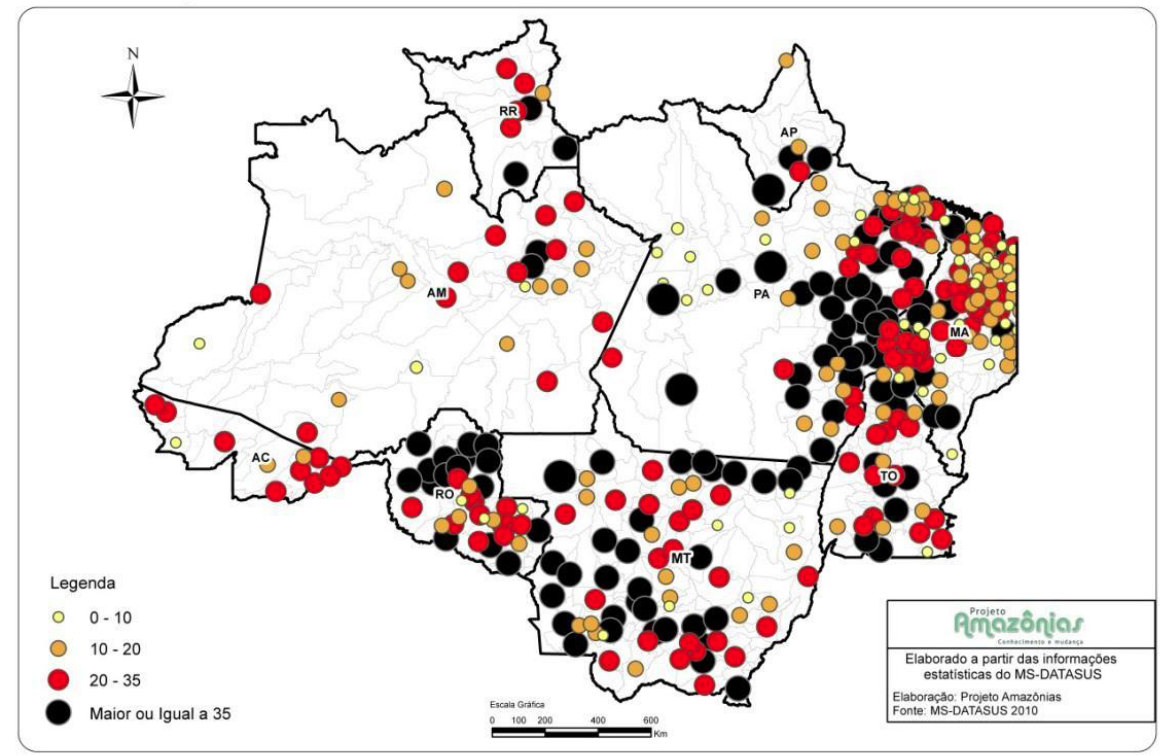

Map 10: Homicide rate per 100.000 inhabitants in the legal amazon municipalities, 2010 (2 ${ }^{\mathrm{ND}}$ visualization, scatter plots).

The study demonstrates, however, that the evolution of homicides by firearm in the country is not homogeneous in the brazilian territory; on the contrary, it varies a lot according to the region. While States of the brazilian South and Southeast Regions, like São Paulo and Rio de Janeiro, were able to reduce their mortality rates, States like Maranhão and Rio Grande do Norte, quadruplicated their ocorrences.

The "Atlas of Violence" $(2017)^{3}$ recently published by the Brazilian Institute of Applied Economics (IPEA), analyzes the homicides in Brazil in the period of 2005 2015 , and makes similar observations, demonstrating that the states that presented superior growth than $100 \%$ in the rates of homicide in the period are located in the North and Northeast regions. On the other hand, it shows that the most significant reductions were in states of the Southeast: in São Paulo, the rate fell $44,3 \%$ (from 21,9 to 12,2 ), and, in Rio de Janeiro, it fell $36,4 \%$ (from 48,2 to 30,6 ).

The Atlas also indicates a strong diffusion of the homicides to municipalities of the outback of the country, and indicates that Altamira, in the State of Pará, now leads the relation of the most violent municipalities of Brazil. The evolution of homicides by firearm concentrate more strongly in states of the North and Northeast region, many of which, like Pará and

${ }^{3}$ CERQUEIRA, D.; LIMA, R. S.; BUENOS, S.; VALENCIA, L.I.; HANASHIRO, O.; MACHADO, P.H.G.; LIMA, A.S. Atlas of Violence. $2^{\circ}$ Ed. Rio de Janeiro: IPEA, 2017. parts of Maranhão, are territories which are historically situated at the frontier of the economic and social development of the country.

Furthermore, both studies point strongly to a similar profile for the victims, affirming that black young people of male gender are the main victims of this violence. The "Map of Violence" (2016) indicates that, while in the whole population the increase of homicides by firearm grew $592,8 \%$ in the period comprehended between 1980 and 2014, the number went up to $699,5 \%$ among young people (age 15 to 29 ). Besides age, what the victims have in common are the color of their skin and their gender: $94,4 \%$ amongst the victims are men and proportionally, black men suffer $158,9 \%$ more homicides than white men (2,6 black men die for each death of white men).

The "Atlas of Violence" (2017), indicates that more than 318.000 young people have been assassinated in Brazil between 2005 and 2015, having in common the same age, gender and race: more than $92 \%$ are men, and for each 100 murdered people in Brazil, 71 are black people. According to the information of the Atlas, black people have $23,5 \%$ more chances of being murdered in relation to Brazilian people of other races, discounting the age, education, gender, marital status and neighborhood of residence.

This scenery has been strengthened in the last years, mainly, by the exacerbated use of police force and, more recently, by the appearing of extermination 
groups and militia, composed by inactive or active public safety agents and also by particulars, causing slaughters in all the Brazilian territory. It's no wonder that the "Atlas of Violence" presents important data about deaths caused by police intervention, based on the analysis of the numbers of the MIS (Mortality Information System - DATASUS) in the "legal interventions and war operations" category registered 942 cases of legal interventions (despite the high level of subnotification) between 2005 and 2015. The public safety authorities registered 3.320 deaths caused by police intervention, that is, 3,5 times the number of health registers, also between 2005 and 2015 .

The data here presented, besides pointing the increase of mortality by firearm in the Amazon and its selectivity in relation to the poor, black and peripheral youth, demonstrates that death, despite being a natural fact and inherent to human condition, have showed itself in the recent years as a phenomenon of more social and political character. Besides the increase of the number of death occurrences caused by firearm, grows, in equal proportion, the social clamor that tolerates or openly asks for the death of groups considered dangerous, which the youth of the peripheral neighborhoods are nowadays pointed out as the main representative.

\section{Homicides and Social Diversity in the Amazon}

In our avaliation, the homicides of the peripheral youth in the Amazon may be related to a problem of social diversity. We can say that, just as the term biodiversity appeared to have helped the Market to continue its exploration of natural ressources, so does the concept of social diversity in relation to the Marketoriented valuation of human beings. With a few decades of experience, we can observe that in numerous cases, the first purpose of the concept of biodiversity has been corrupted from its original goal (protect every biological expression) in order to use the environment as a conceptual cover-up of most of the Market-oriented biodiversity attacks, particularly through the repression and criminalization of smaller development projects, less useful in the process of capital accumulation than the "great" ones. The example of the construction of the Belo Monte hydroelectric power station in the federated State of Pará belongs to this Market-oriented logic, in spite of its impacts on local environment and traditional populations.

If we pay greater attention to Amazonian populations, following the same logic, the notion of "social diversity" could be used to pretend to protect some populations, with the purpose of hiding a great wave of erasing Amazonian social diversity, which means the systematic annihilation of the capacities of cultural and financial survival of the poor and vulnerable populations, as they are considered "useless" from the new Market-oriented point of view.

In the last decade, a specific form of violence in urban areas has strengthened in the Brazilian Amazon stage: the killing of peripheral poor black youth. The action of killing several people at the same time (or in sequence), in a particularly cruel and brutal way, has become frequent in contemporary Amazonian reality and imposes on the Amazonian urban areas true scenes of extermination of peripheral populations. These multiple killings (chacinas), which penetrate more deeply each year the Amazon network of inner cities (traditionally marked by the social assassinations of trade unionists and landless rural workers) have found widespread support and publicity in local and national media, as such as criminal justice burocrats, which, associated with indifference or connivance of the economic rulers, have contributed to the legitimization of the coercitive power, naturalizing the massacre as well as the massive incarceration of the Amazonian peripheral youth.

Locally, the "chacinas" killings have been systematically justified by leading opinion makers (politicians and local media agents). In the perspective of biopolitics, this power to eliminate lives finds its raison d'être in the use of race as a criterion for discriminating and hierarchizing the human life forms. Michel Foucault called this phenomenon the "State Racism" (FOUCAULT, 2005). In this matter, race is understood as the epistemic cut between those who must live and those who can die. In this way, even in a society in which life is guaranteed as a fundamental right, its suppressing becomes acceptable when race is used to remove from society those who are labelled as "dangerous". To find out to what extent these urban slaughters in the Amazon region are promoted or opposed by the neoliberal law enforcement agencies must pass trough a preliminary theorical question: In relation to the neoliberal art of government, to what extent would we be witnessing, in the Brazilian Amazon, a process of eliminating the life forms that are contrary or useless to the "Market"?

This question that tries to analyze what would be the relation between neoliberalism and the physical annihilation of the Amazon youth is anchored in a 
literature that already points in the direction of a normalizing and erasing purpose of neoliberal governmentality. According to Michaël Fœssel,

Neoliberal society organizes the exclusion of those who can not see and remain "blind" to Market opportunities. These ones become guilty by lack of vigilance. They are irrational agents in a world saturated with technical rationalities and useful informations. [...] Their fault lies in a deficit of adaptation (FOESSEL, 2010: 46, our translation).

In this regard, it is possible that the main functions of normative dispositives may be to define what is "useful" and what is "allowed" in the (e)valuation of the "Market". Thus, when we consider preventive and repressive action in the criminal area, on the one hand, we seek to "readapt" those who are no longer acting according to the Market rules, and, on the other hand, those who are already distanced, (poor, Indigenous, crazy, etc.), in relation to whom the Market evaluates that they themselves have definitively placed themselves outside the economic game.

In the book La Société Punitive, Michel Foucault goes even further:

from the moment that society defines itself as the system of relations of individuals that make the producting process possible, in order to maximize it, we have a criterion that allows us to designate the enemy of the society: any person who is hostile or contrary to the rule of maximizing production (FOUCAULT, 2013: 53, our translation).

The "Market", regime of truth of neoliberal governmentality (FOUCAULT, 2008), has the responsibility and privilege of delimiting the boundaries of the abnormal, of the "weed", for its own interest. For this reason, security nowdays turned into a importante pillar of neoliberal governmentality: it has the dual function of preserving the possibility of trades taking place with the greatest possible security and of defining the danger to be eliminated by the law enforcement and risk management agencies. At the same time, security and risk issues, in the neoliberal ratio, carry out a structuring of the essential node of the Market economy (the regulation of economic Market transactions) and a peculiar treatment of Market margins (governmental and moral regulation of social behaviors, as well as marginalization of deviant behaviors). Once again, the Market is instituted as a regime of truth; moral and ethics have to conform to what is defined as true or false, which means separata and (e)valuating what is good and what is bad in the perspective of economic freedom and wealth accumulation.

Considering that the security that corresponds to neoliberal governmentality has as its essential object the protection of the market trades, the normative agencies (and especially those of law enforcement) must adapt to new challenges and prioritize economic considerations upon justice and social peace. In Brazil, and particularly in the Brazilian Amazon, numerous resources are applied to the security of the banks and the major economic actors in the region (landlords in the rural areas, and big corporations in the metropolitan region) and these investments are transformed into specific policing programs, all of them exclusively Market-oriented. On the other hand, throughout years of experience in studying public security policies in Brazil, it has been quite impossible to read a serious policing program aiming specifically a popular neighborhood safety. An exception to this latest argument is the case of emergency policing, during which the police operation is turned into a spectacle aimed at the press and public opinion, a glitter for the eyes of the electorate, a neoliberal biopolitical object.

By addressing the "reasonable man", and in order to normalize behavior to best suit the Market, neoliberal governmentality helps to stage a society of risk and conjuration of the future, in which risk management only serves as a smokescreen for the promotion of fear, also for Market-oriented purposes. For the social scientist Robert Castel, this "culture of risk" also turns into a danger factory (CASTEL, 2003: 60).

In reality, the neoliberal concept of security has a double dimension: the social insecurity created by the economic order and social competition corresponds to the need to mobilize the sectors of public security, criminal justice and penitentiary administrations, which is transformed in an individual insecurity among citizens who massively get to support repressive safety policies. Under these conditions, security and criminal justice almost exclusively play a role in providing a response to social fears. The social scientist Loïc Wacquant also observes that the adoption of essentially repressive criminal policies corresponds to an effort to "legitimize the police and judicial 
management of the poverty that bothers" (WACQUANT, 2011: 38, our traduction).

All the processes described here are in accordance with those that Foucault associated with the concept of biopolitics or biopower; individuals are controlled as a population in an era in which security imposes itself as an essential framework for government action, based on the regime of truth constructed by the "natural laws of the Market" (FOUCAULT, 2008).

The law of the Market has to be put in perspective with the principle of "social utility," which is determined from an exercise in valuating life. This valuation also contributes to defining or discriminating which life forms deserve or do not deserve to be lived. In extreme cases, it also decides which ones need to be erased or exterminated, as if we were in a gigantic open-air concentration camp, as says Giorgio Agamben (AGAMBEN, 2012). Considerations about the "life worth to be lived" and "life unworthy to be lived", as well as considerations about the useful life and useless life can be referenced for various life forms, both in biological life (the extermination of a mosquito, a virus or any "plague" or "weed" whose usefulness has not been demontrated) and in social life (the removal or annihilation of individuals or intra-individual qualities that are judged not compatible with the development of a harmonious social life: chemical castration, incarceration, extermination of young peripheral people, anti-smoking propaganda, hierarchy of sexualities and genders, etc.).

In the Brazilian Amazon, it seems nowdays important to study the institutions, agents and government practices that serve to carry out this triage between what is useful for the Market and deserves to live, and what is useless for the Market and deserves to die.

\section{The Extermination of the Peripheral Youth in the Amazon}

In the Amazonian State of Pará, the reality of the production of mass deaths presented earlier has also as a main target the peripheral youth. It's no wonder that the Investigation Parliamentary Comission "CPI of the militia", installed by the Legislative Assembly of the State of Pará, found out the existence and the action of extermination groups and militia in a large scale in Pará territory. The investigation performed by the CPI was concentrated in the Metropolitan Region of Belém, the State Capital, which appeared to be a fertile territory of action of these groups, where various slaughters were fulfilled, as in the interior of the State, specifically in the cities of Marabá and Igarapé-Miri.

Far from causing repulse or social commotion, the occurrence of such deaths seems to receive a wide support of the largest part of society, of the media, of the State's devices and, therefore, of the State itself, that seem to consider the extermination of these lives as something beneficial to the population as a whole. This is the observation made by State Deputy Carlos Bordalo, reporter for the militia CPI in Pará:

In the studies made in Pará two nefarious dimensions of the phenomenon of the death of black and poor young men are perceived. The first one is evidenced by the speech of legitimization of the murderers and by the criminalization of the victims, seen always as "bums", "debtors", "potheads" or "with police record", this speech synthesized in the expression "a good bandit is a bad bandit" is reinforced daily by journalists and communication vehicles in the written, spoken and television press in a way that has become a mantra already assimilated by the largest part of the population, including the one subjected to these murderers ${ }^{4}$.

Convinced by these disqualifying speeches and considering the arbitrary actions of extermination groups as beneficial, the sectors of society have been legitimating the deaths occurred in slaughters and, therefore, adhering to the common generalized sense that comprehends the phenomenon of violence as something evident, of easy resolution and with magical quick answers. However, a critical analysis of the strands of social violence, like the question of deaths in slaughtering, can never be interpreted as evident. It is needed, before all, to analyze the relations of power that institute such problems, as well as its political and symbolical effects, denying the first experience of the world, that is, the common sense disseminated in the social body, like the objective of making reappear the conflicts and wills that originated this natural appearance of things. As for that, more than necessary the observations of the sociologist Pierre Bourdieu:

${ }^{4}$ BORDALO, Carlos. Situation of extermination cases of young blacks from the records of the human rights commission of the legislative assembly of the state of Pará. In Segurança Pública e Justiça: Direitos Humanos na Amazônia. OLIVEIRA, Anna Claudia Lins (Org.). Belém: Anna Claúdia Lins, 2015, p.141. 
What is presented today as evident, acquired, established for once and for all, out of discussion, was not always like this and it was only imposed as such little by little: it's the historical evolution that tends to abolish history, principally returning to the past, that is, to the unconscious, the possible laterals that were discarded, in this way making it be forgotten that the 'natural attitude' referred by the phenomenologists, that is, the first experience of the world as something evident, constitutes a socially constructed relation, like the perceptive schemes that make it possible ${ }^{5}$.

Because of that, we understand that the problem of the extermination of young people exerts, presently, a specific function inside the neoliberal political order, that ends up revealing the strategies of the neoliberal government model that supports the development of the current capitalism. That because, according to Michel Foucault, the power in neoliberalism has two purposes: to make live and to let die; the first referring to the individuals that correspond to the expectations of the hegemonic norms of capitalism and that, because of that, have their lives be respected and valued, and the second refers to the people that are located outside this order and for not being useful to the capital, may confront various forms of coercion and disqualifications expressed in these speeches. Starting from the neoliberal rationality, groups with poor people, black people, gay people, women and traditional people, among many others, suffer forms of degradation and discrimination in society, since they don't correspond to the model of normality of the neoliberal life.

The let die, by its turn, has been accepted by society, as the neoliberalism has used racism as a point to convince the population that the death of these groups represents the betterment of social living. Racism here understood as not only racial violence against black people, but as "[...] the cut between what must live and what must die". And in the neoliberal order, who must die are those that haven't given their ways of life to the normalization process imposed by the logic of the neoliberal market, that is, all those who deviate from the business man model. Such subjects represent a danger to the normalized life created by

${ }^{5}$ BOURDIEU, Pierre. Meditation Pascalianas. Rio de Janeiro: Bertrand. Brasil, 2001, p. 211-212. contemporary capitalism and because of that, over them falls a series of speeches that disqualify their lives and that allow their elimination from social living.

In other words, to take away the life, the death imperative, is only admissible, in the system of the biopower, tends itself not to the victory over the political adversaries, but to the elimination of the biological danger and the strengthening, directly linked to this elimination, of the species or race itself. The race, the racism, is the condition of acceptability of taking life in a society of normalization ${ }^{6}$.

In this environment, death is produced to produce normalized life. That explains, therefore, the fact that the large part of the peripheral youth is the target of speeches and institutes that consider them "bandits", "misbehaved", "bad citizens", that can be eliminated by the system of criminal repression, because they are out of the neoliberal normality. Media, public safety organs and common citizens reproduce these speeches, that disqualify these lives as if they were inferior, and end up justifying the extermination of this population.

That is shown most evident principally in the contact of the victims with the police and the criminal system as a whole. In interviews fulfilled with the relatives of the victims of extermination in the Amazon, in the context of the scientific initiation program - $\mathrm{PIBIC}^{7}$, of the UFPA, we can observe that there are reports of the relatives that point to a differentiated treatment experimented not only by the victims, but also by themselves, especially when in contact with the police and the criminal system. It is perceived that this treatment clearly has a discriminatory content, because it is based on the racist idea that such people are less deserving of respectful treatment than the others, including by the state institutions. The interviewed Suelen comments that her husband was badly treated by the police, that saw him as a drug dealer and, therefore, deserving of humiliation and disrespect.

INTERVIEWER: How was he treated by the police?

INTWERVIEWED: Look, as I told you, he was really seen by some as a drug dealer,

${ }^{6}$ FOUCAULT, Michel. In defense of society: course at the Collége de France (1975-1976) . São Paulo: Martins fontes, 2000, p.306.

${ }^{7}$ FIELD NOTES. Interviews conceded to Amanda Laysi Pimentel dos Santos Belém, oct. and nov., 2016. 
because he didn't work, but he liked to dress nice. Then they wanted to know where his clothes came from, which, poor man, it was Gina (sister-in-law) who gave them to him. He, for being a big guy, the same image that the boys had of him, the police also had it. He ended up being beaten in the park, because of a shirt that was using which was really expensive, that he was given by Diana (cousin). Then the police officer simply wanted to take the shirt off him and even beat him there at the park. In his head he couldn't have a shirt like that.

Also, the interviewed Lourdes, from the municipality of Igarapé-Miri/PA, reports the abusive treatment performed by the police. To her, the police officers considered the young people that lived in her neighborhood (significantly christened as "Africa", due to the great number of black skinned residents), as dangerous and that because of that, treat them and all the residents in a disrespectful way.

Yes, so many times, the police itself, it only knows to see one side, it doesn't know how to see the other one. Sometimes everything that happens, for them it's the boys from Africa. They don't seek to know if it is, if it isn't, what happened, no! They already come in here. If in a neighborhood something happens, they come here directly. That sometimes revolts the population in the streets, because they can only see one side, not the other. We know that they are not perfect, because perfect really is only God, but they have to glance at both sides of the coin, not just one side. [...] They call us vagabonds, it's like this, it's only like this that they call us, they call everyone vagabonds.

This progressive disqualification of life that the youth has been suffering and the one that Foucault called state racism, is the justification used by neoliberalism to legitimate the elimination of marginal groups as the danger to be removed from normalized social living. The extermination, therefore, is a device of the production of disqualifying of life speeches and practices, that classify the individuals as good and bad, according to their adequacy or not to the political project in force.
The neoliberalism permits to stage, in this context, a rationality that articulates to the promotion of a vitality of the social body, which leads, in reality, to a certain eugenics that aims to eliminate those who seem socially weaker. The extermination, in this way, appears as a project of elimination of the lives considered inferior and superfluous, that represent a danger to the dignified lives of society (useful to the economy).

\section{Observations for a Political Confrontation of the Public Safety in Brazil}

The analysis of the lethal violence and the extermination of youth in the Amazon can't be unlinked from a global reflection about violence, and especially about the ways and conditions of its expression in Latin America and in Brazil. The violence expressed by weapons is no doubt the most visible, but this is only the prolongation of a symbolic, physical and hegemonic violence that are part of, structurally, of the structure of the Brazilian society, in its various dimensions (economic, social, political).

The social agony, symbolical and physical, that the peripheral youth live, the atomization and the lack of solidarity from the common classes (presented ideologically by the opposition between, on one side, the "pacific, humble, honest hardworker" and, on the other side, the "idle, violent, impertinent, dishonest marginal") are phenomenons intimately linked to the model of neoliberal government that sustains the development of the current capitalism, in its primordially financial phase, which is less consuming of work force than its precedent industrial phase.

The cynical association made between impoverished territories and the organized crime (or disorganized) serves a clear purpose: the disorganization of the lower classes by an ideological construction that promotes the atomization of interests and the war of each against each, at the same time it promotes the snuffing out of the internal conflicts of the upper class, whose interest in the definition of an empty universal has never been so clear ${ }^{8}$.

In these conditions, to construct proposes for the public safety means to take into consideration the context of which the criminal violence exerts itself, and the interests that it serves. Why, what is the

${ }^{8}$ In the 1970's, Nicos Poulantzas had already described this phenomenon in his book The State, the Power, the Socialism. 
environment of the exercise of public safety? The current neoliberal governmentality promotes a generalized competition between individuals, groups and social networks, from a promotion of the concurrence principle, as well as the relevance and the merit of an exclusive defense of their particular interests (at least the socially recognized interests because it seems impossible to determine with accuracy in what reside our interests). The generalized competition between homioeconomici and the transformation of the individuals and the social groups in companies moved only by interest creates the favorable environment to the realization and the justifying of a society founded in the war of each against each.

This war, inevitably, reaches each social relation and any type of institution, group or individual ${ }^{9}$ : it's the sense of the inversion of the aphorism of Carl von Clausewitz by Michel Foucault:

And if it's true that the political power for war, makes reign or try to make reign a peace in the civil society, it is not at all to suspend the effects of war or neutralize the imbalance that has manifested itself in the final battle of war. The political power, in this hypothesis, would have as a function to perpetually reinsert this relation of force, by a species of silent war, and of reinserting it in the institutions and in the economic unequalities, in the language, and even in the bodies of ones and others $^{10}$.

How to expect a social or civic peace in a society that has as a major rule of sociability the generalized war between individuals, and particularly of the common classes against themselves? Also, how to achieve "peace" when the main institutions attend almost exclusively to the interests of the dominant class, assuming the functions of conflict mediating of the most stocked social class and the systematic repression of the promotion of interests of the common classes? The function of the police force is inserted in this environment, and it's not strange if the police as an armed force serves the main interests defined by the ideological and institutional frame in which it is inserted.

${ }^{9}$ DELUCHEY (J.-F.), "Profanar os direitos: as crianças no campo de batalha", 26/03/2015, Empório do Direito, 5 pages. Available online in the following url: http://emporiododireito.com.br/profanar-os-direitos-as-criancas-no-campo-debatalha-por-jean-francois-y-deluchey/

${ }^{10}$ FOUCAULT, Michel. In defense of society: course at the Collége de France (1975-1976). São Paulo: Martins fontes, 2000, p. 23.
Reverting the increasing of lethal violence in the Amazon, as well as the role of the police in this endeavor must pass by a reformulation of the rules of socialization promoted by the neoliberal governmentality. This reformulation is still more important on the Amazon, eternal pioneer region of the Nation, in which the extrativism and the predation of natural resources have become intrinsic processes of the "development" projects in the region, systematically encouraged by the government institutions. But the necessary reformulation of the governmentality in force must by its turn pass by another reformulation: the reaffirmation of the citizenship of the Brazilian demos and, therefore, the renovation of the democratic project in the country.

The model of community police enforcement, experimented in multiple occasions and in multiple territories (with sometimes contradictory genres that contributed to the emptying of the concept itself of community police), was presented in 1990's and the 2000 's as an attempt of "democratization" of the sector, starting from the population participation in the defining of the priorities related to the safety of the respective territories.

This participation of the population, in almost all the fulfilled experiences, was extremely scarce and generally it reduced itself to asking the opinion of the territory resident commons about the safety situation and the possible solutions to invent to confront the types of violence and the criminality that there expressed themselves (this, when the exercise didn't correspond to a simple electoral sponsorship of the neighborhood population by "electoral cables" of the parties allied to the government) ${ }^{11}$. This type of participation generally used the model of public opinion research, in as contradicted to the principle of deliberation that were supposed to characterize a democratic practice.

With the disqualification of the democratic deliberation arenas, seems little probable the apparition of a democratic police enforcement model marked ideally by various characteristics: decentralization of the decisions, reinforced professional ethics, professional qualification, combat to the ideological militarization, promotion of the public interest,

\footnotetext{
${ }^{11}$ DELUCHEY (J.-F.), "The organized civil society and the governmental administration of interests: the example of the couple councils", In Revista Estudos Políticos , N.5, 2012/02, p. 77-101. Available online: http://revistaestudospoliticos.com/wp-content/uploads/2012/12/5p77-101.pdf .
} 
protection to the most vulnerable populations, popular social control over the police activity, precision in the definition of institutional competences, transparency of the statistics and accountability practices of the offered services, popular deliberative participation in the elaboration of guidelines for the sector, etc.

For this objective, the way of thinking the public safety must be the object of ample revision. Currently, safety in the neoliberal governmentality has as its essencial functions to guarantee the freedom of the entrepreneurship and offering security to the exchanges between economic agents. The devices of criminal repression are taken to adequate to these challenges, giving priority to the market global players' interests in detriment of the objectives of justice and social peace. In Brazil, and particularly in the Amazon, numberless resources are applied to the safety of banks and main economic actors of the region (farmers and great mineral or hydroelectric projects in the interior, major companies in the biggest urban poles). The police, in its treatment of the conflicts between citizens, usually prioritize the patrimonial conflicts, opposing popular classes and favored classes, and silencing the conflicts between classes that bother the day-to-day of the popular classes, preferring to these the treatment of conflict mediation, passing then to the large of the legal system of criminal repression ${ }^{12}$.

We can only agree with German philosopher Michael Foessel when he observes that safety has become a condition of accumulation of riches, constituting then the main "ethos of the market"13. In this situation we must recognize that safety, allied with risk, is treated in the neoliberal order in its negative dimension. Both end up being greatly promoted in the neoliberal order for representing the conditions of organization of the social relations as from an individual calculus, in which insecurity and fear are the main characters in the scales and, therefore, the main motors of the society of control described by Michel Foucault or Gilles Deleuze ${ }^{14}$.

In this society, the market is the regime of truth that rules the government actions started from a cost/benefit calculus referring to an economic rationality, and that cost/benefit calculus is market-

\footnotetext{
${ }^{12}$ OLIVEIRA, Luciano. Polícia e classes populares. Cadernos Estudos Sociais , 1(1), jan-jul 1985, p. 85-96.

${ }^{13}$ FOESSEL, Michaël. État de vigilance. Critique de la banalité sécuritaire ..., p. 43, traduction at liberty.

${ }^{14}$ FOUCAULT Michel (2008), Nascimento da Biopolítica , São Paulo: Martins Fontes.
}

centered: it doesn't intend to reach, as in the last classis utilitarianism (and, by way of consequence, of symbolic capital). Therefore, it is submitted all the individual and collective strategies to an only purpose of each the human being and its happiness, justice and social peace are completely absent, because they're not pertinent. Antoine Garapon had pointed the antidemocratic character of the neoliberal rationality. For him, the neoliberalism "proposes to replace the collective deliberation and the discussion of what's legitimate and what's illegitimate by a concrete and more modest organization of society, more effective and efficient, founded in the individual liberty. In this sense, it constitutes a philosophy of a politician's outing." The author follows: "The neoliberalism is an abstract system, formal, particularly ambitious because it intends to be able to liberate itself from the politics and justice. No more, no less" ${ }^{15}$.

By the rationality adopted by the neoliberal governmentality, the government is obligated to attend essentially to the interests of the biggest players of the economic game, forgetting in the way about the democratic dictates that offers it its institutional normative frame. In this context, the public safety device aims essentially to market securization, leaving behind any real ambition of bringing individual security to the great majority of Brazilian citizens. This explains why the public safety never really integrates the political debates, unless to serve as a scarecrow and mobilize the resource to the order to legitimate a speech that is essentially conservative, repressive and negatively discriminating in relation to the popular classes and the social movements. This explains also why the question of the increase in public safety budget can't enter the agendas of the federal or state police forces, once the main functions that are attributed to them are already sustained by the budgets currently dedicated to the "public" safety, a budget increase is perceived as useless.

Besides the extreme complexity and paralysis imposed to the sector of public safety by the current Brazilian federative pact and the constitutionalization of the institutional organization of this public sector, we have to recognize that until today no political pact was built in relations to public safety. There was supposed to be a regular reunion between social scientists, police officers, social movements and elected representatives

\footnotetext{
${ }^{15}$ GARAPON, Antoine. La Raison du moindre État. Le néolibéralisme et la justice ..., p. 24 e 43, traduction at liberty.
} 
to found the basis of a continuing political reflection in relation to public safety that sets an ample political pact in the sector.

We know that public safety is the last link in the chain of the organization and implementation of the public policies, but while the Brazilian social order remains founded in insecurity and in a war of each against each, and while the spaces of citizen expression and of solidarity remain marginal or nonexistent, the public safety policies can only aim to the maintaining of a social order too unequal to be truly democratic.

\section{REFERENCES}

AGAMBEN (2012), Giorgio. Homo Sacer: O poder soberano e a vida nua I, Belo Horizonte: Editora UFMG, [1995].

BORDALO, Carlos (2015). Situation of extermination cases of young blacks from the records of the human rights commission of the legislative assembly of the state of Pará. In Segurança Pública e Justiça: Direitos Humanos na Amazônia. OLIVEIRA, Anna Claudia Lins (Org.). Belém: Anna Claúdia Lins.

BOURDIEU, Pierre (2001). Meditation Pascalianas. Rio de Janeiro: Bertrand. Brasil.

CASTEL, Robert (2005). A insegurança social: O que é ser protegido ? Petrópolis: Vozes.

DELEUZE Gilles (1992), Conversações, Rio de Janeiro: Editora 34.

DELUCHEY Jean-François (2015), "Profanar os direitos: as crianças no campo de batalha", 26/03/2015, site internet Empório do Direito, 5 páginas. Disponível on line no endereço seguinte: http://emporiododireito.com.br/profanar-os-direitos-ascriancas-no-campo-de-batalha-por-jean-francois-y-deluchey/.
(2005), Vitimização, Insegurança e Segurança Pública no Estado do Pará: um Diagnóstico, Belém, Relatório final da pesquisa "Diagnóstico da Segurança Pública no Estado do Pará", 2005, 182 p.

DELUCHEY Jean-François, BRITO Michelle B. (2014), "Políticas públicas e soberania popular: por uma refundação democrática da segurança pública". In DIAS Jean C., GOMES Marcus Alan M. (eds.). Direito e Políticas Públicas, Belém, MÉTODO/CESUPA, p. 203-226.

FATTORELLI Maria Lúcia, ÁVILA Rodrigo (2015), "Gastos com a Dívida Pública em 2014 superaram 45\% do Orçamento Federal Executado", site internet Auditoria Cidadã da Dívida, 05/02/2015. Acessível em: http://www.auditoriacidada.org.br/ e-por-direitos-auditoria-da-divida-ja-confira-o-grafico-doorcamento-de-2012/.

FOESSEL Michael (2010), État de vigilance. Critique de la banalité sécuritaire. Paris : Ed. Le Bord de l'Eau.

FOUCAULT Michel (2005), Em defesa da Sociedade, São Paulo: Martins Fontes, 2005 [1976].

FOUCAULT Michel (2008), Nascimento da Biopolitica, São Paulo: Martins Fontes [1979].

FOUCAULT Michel (2013), La société punitive, Paris: Seuil/Gallimard [1972].

GARAPON, Antoine (2010). La Raison du moindre État. Le néolibéralisme et la justice. Paris : Odile Jacob.

OLIVEIRA, Luciano (1985). Polícia e classes populares. Cadernos Estudos Sociais, 1(1), jan-jul 1985, p. 85-96.

ROSA Hartmut (2012), Aliénation et accélération. Vers une théorie critique de la modernité tardive. Paris : La Découverte.

UNITED NATIONS OFFICE ON DRUGS AND CRIME (2011), 2011 Global Study on Homicide. Trends, Contexts, Data. Viena: UNODC.

WACQUANT Loïc (2011), As prisões da miséria. 2. Ed., Rio de Janeiro: Zahar.

DOI: https://doi.org/10.6000/1929-4409.2018.07.16

() 2018 Deluchey and Santos; Licensee Lifescience Global.

This is an open access article licensed under the terms of the Creative Commons Attribution Non-Commercial License (http://creativecommons.org/licenses/by-nc/3.0/) which permits unrestricted, non-commercial use, distribution and reproduction in any medium, provided the work is properly cited. 